ACTA ARACHNOL., XXV, (2), 1974.

\title{
Neurosecretory Cells and Their Ultrastructures of Rhipicephalus sanguineus (LATREILLE) (Acarina : Ixodidae) ${ }^{1)}$
}

\author{
Y.S. CHOw and C. H. WANG \\ Institute of Zoology, Academia Sinica \\ Taipei, Taiwan, Rep. of China
}

\begin{abstract}
In the brain of the brown dog tick, Rhipicephalus sanguineus (LATREILLE) 15 groups of neurosecretory cells are divided into 2 types, $\beta$ and $\alpha$ cells. Among $\beta$ cells, the function of the groups $2-5$ in the dorsal ganglion are correlated with ecdysis, whereas group 18 in the ventral ganglion is required for the normal development of most tick tissue. Cells of groups $6,7_{2}$ and $7_{1}$ $(\alpha$-cell) $8-9,10,11,12,13,14,15,16$ and 17 are possibly related to digestion and maturation of the reproductive system respectively. The granules of $\beta$ cells can be further divided into 2 groups by electron microscopy: large opaque droplets $1200 \AA-3000 \AA$ in diameter, and small opaque droplets $400 \AA-700 \AA$ in diameter. Lucent vesicles are also found.
\end{abstract}

\section{Introduction}

Douglas (1943) first reported that the brain of the American dog tick, Dermacentor andersoni Stiles is composed of 10 pairs of fused ganglia. TsviLENEVA (1965) further studied the "synganglion" of ixodid ticks by neurohistological methods. IOFFE (1964) and DHANDA (1967) demonstrated 18 groups of neurosecretory cells in Hyalomma ticks. CHOW (1970) and BERGER et al. (1971) reported that the maturation and copulation of both sexes of the Gulf Coast tick, Amblyomma maculatum required attachment of the ticks on the rabbit host for at least 2 weeks. NATHANSON (1970) also reported that the development of the rabbit tick, Haemaphysalis leporispalustris (PACKARD) was related to the tick's attachment on the rabbit. He further showed an important physiological relationship between the integument and anterior consolidated ganglion (brain). All the obtained results indicate that reproduction

1) This research was supported by the National Science Council, Rep. of China. 
in ticks is perhaps controlled by a slow functioning hormonal system. There is a growing fund of knowledge about insect endocrinology (SMITH \& TREHerne, 1963 ; Novak, 1966; Hofer, 1968; PARK \& Yoshitake, 1971; DutKoWSKI et al. 1971), yet little is known about the function of the neurosecretory cells to their target organ in the tick's endocrine system. This paper is concerned with the cyclic changes of neurosecretory material within the brain during different developmental stages and the ultrastructure of granules in the central nerve system of the brown dog tick, Rhipicephalus sanguineus (LATREILle).

\section{Materials and Methods}

The brown dog tick, $R$. sanguineus was cultured in the laboratory on rabbits (BERGER et al., 1971). Adult ticks were divided into 4 different stages: 1. pre-feeding, 2. engorged, 3. oviposition, 4. post-oviposition. Nymphs were divided into 2 groups: Pre-feeding and post-feeding stages. The microtechnique was identical to that reported previously (CHOw, 1970). For whole mount studies, the brain was first dissected and then stained with Victoria blue (DOGRA and TANDAN, 1964). The neurosecretory materials of paraffin sections were stained according to Gomoris' chrome-Hematoxylin phloxine (CHP), paraldehyde-fuchsin (PF) techniques (HumAson, 1967; BURGESS and REMPEL, 1966) and perfermic acid-resorcin fuchsin (ITTYCHERIAH and MARKS, 1971).

Because most neurosecretory neurons are active during the engorged stage of the adult, only the brains of the engorged females were subjected to the ultrastructural studies. The brain were first dissected and fixed in $6 \%$ glutaraldehyde and $1 \% \mathrm{OsO}_{4}$ in phosphate buffer adjusted to $\mathrm{PH}$ 7.3. They were then washed, dehydrated, embedded (Epon 812) and sectioned according to the method described by NATHANSON (1970). For rapid identification of neurosecretory neurons, the periodic acid-basic fuchsin-methylene blue (PFM) method was used (CHOw et al., 1972).

Silver to pale gold sections, after staining with uranyl acetate and lead citrate, were examined in a Hitachi-11-A electron microscope at an accelerating voltage of $50 \mathrm{KV}$. Micrographs were made with Fugi photographic plates. 


\section{Observation and Discussion}

The organization of the brain of the brown dog tick, $R$. sanguineus is similar to the American dog tick, D. andersoni (Douglas, 1943) and that of other ixodid ticks (TSVILENEVA, 1965). It is composed of 2 ganglionic masses, one dorsal (supraoesophageal) and the other ventral (suboesophageal). Although IOFFE (1964) and DHANDA (1967) reported that 18 groups of neurosecretory cells could be defined by PF stain, in whole mount studies of $R$. sanguineus only 2 groups appeared to be Victoria blue positive (Fig. 1). These cells are located on each side of the dorsal mass in the cheliceral ganglia and are referred to by IOFFE (1964) as the "dorsal-lateral group 25." On either side of brain outside the periganglionic sinus, there are 2 pairs spherical structures: the 1st pair is situated between the pedal nerve 1 and pedal nerve 2, the 2 nd pair is situated between pedal nerve 2 and pedal

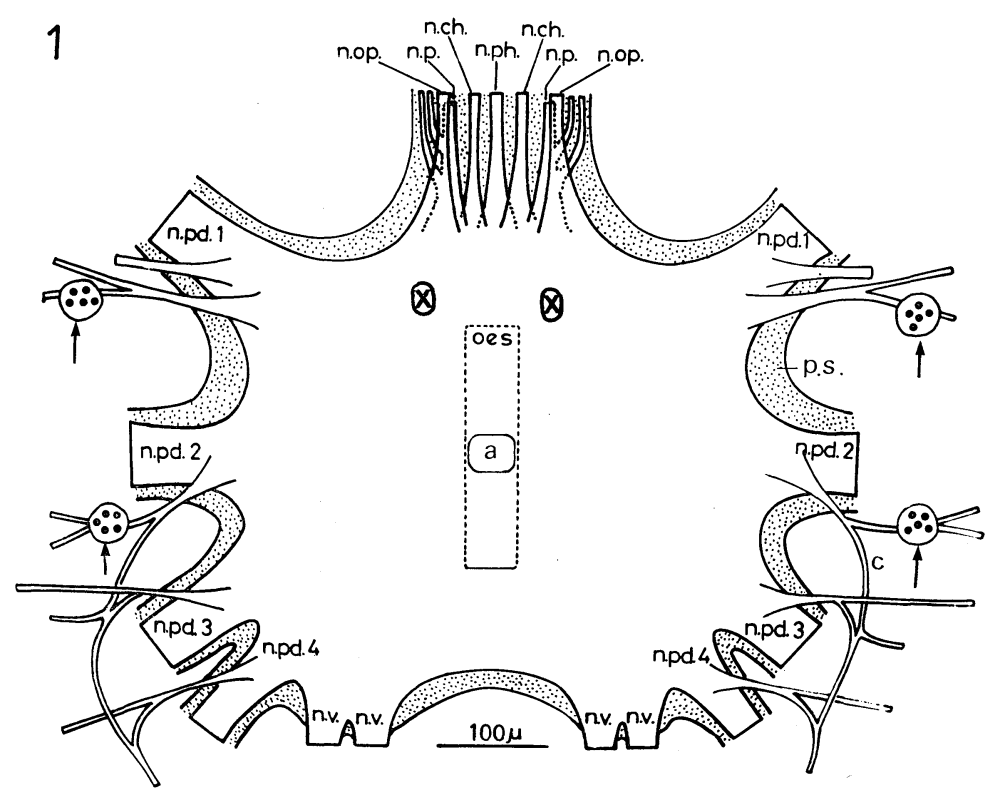

Fig. 1. Doosal view of brain of male brown dog tick, $R$. sanguineus, showing spherical structures (arrow), pedal nerve 1,2, 3 and 4 (n.pd. 1, 2, 3 and 4); circular nerve (c); entrance of aorta (a); oesophagus (oes) and 2 groups of Victoria blue positive neurosecretory cells $(\otimes)$. Optic nerve (n.op.); palpal nerve (n. p.) ; cheliceral nerve (n. ch.), pharyngeal nerve (n. ph.) ; visceral nerve (n. v.) ; periganglionic sinus (p.s.), (Whole mount, Delafield's hematoxylin). 
nerve 3. These structures have fibers connected laterally to the base of the brain on one side and to the ventral or dosal peripheral region of the other (Fig. 1). The 2nd pair is also connected by a small nerve around the brain at each side, as in the chain ganglia of higher animal or somatic ganglia of insects. These spherical structures are $0.06 \mathrm{~mm}$ in diameter. They appear similar to the swellings of the transverse nerve in stick insects (FINLAYSON and OSBORNE, 1970) when DELAFIELD's hematoxylin and methylene blue are applied. Within each structure 3 to 5 big granules were stained with Victoria blue (Fig. 1), but we failed to demonstrate any axon flow to them with

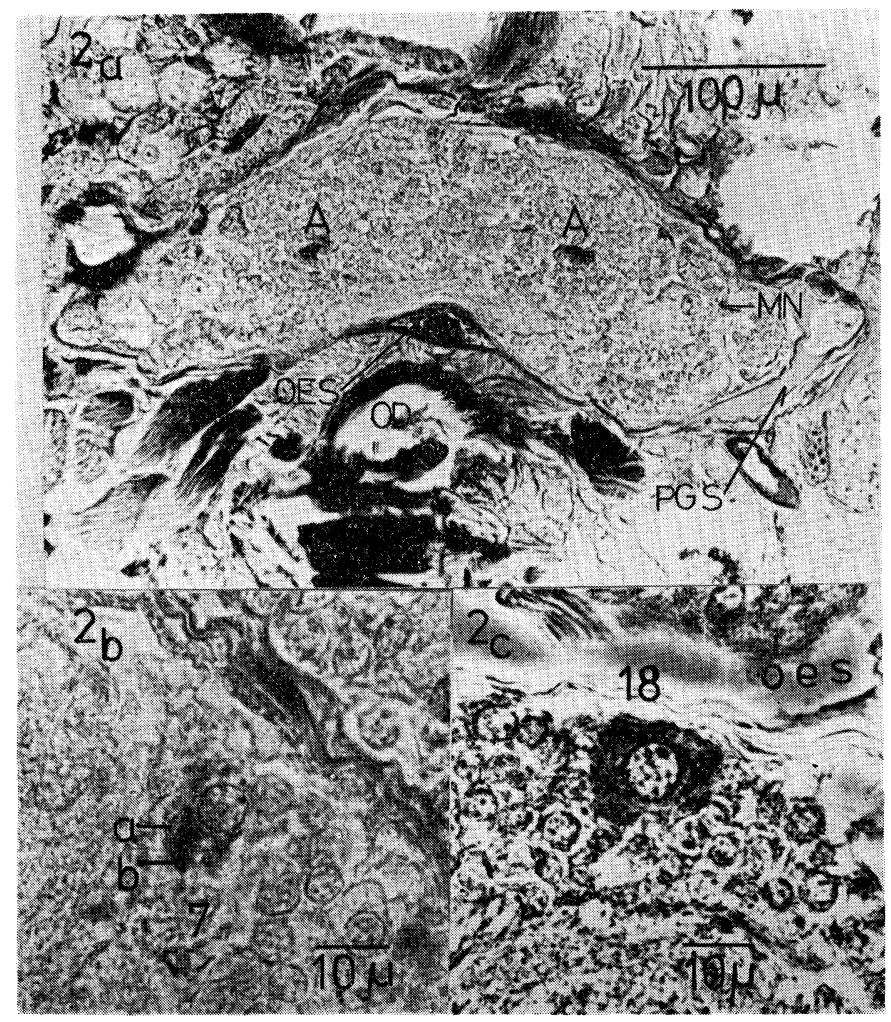

Fig. 2. a. Cross section of dorsal ganglion showing 2 symmetrical grouped 2-5 (A) neurons, motor neurons $(\mathrm{mn})$, oesophagus (oes), periganglionic sinus (PGS), oviduct (OD). (PF stain).

b. Photomicrograph of cell $7_{1}(\alpha$-cell $)$ which contain 2 kinds of particles: acidophilic (a) and basophilic (b). (PF stain).

c. Photomicrograph of grouped cell 18. oes: oesophagus (PF stain). 


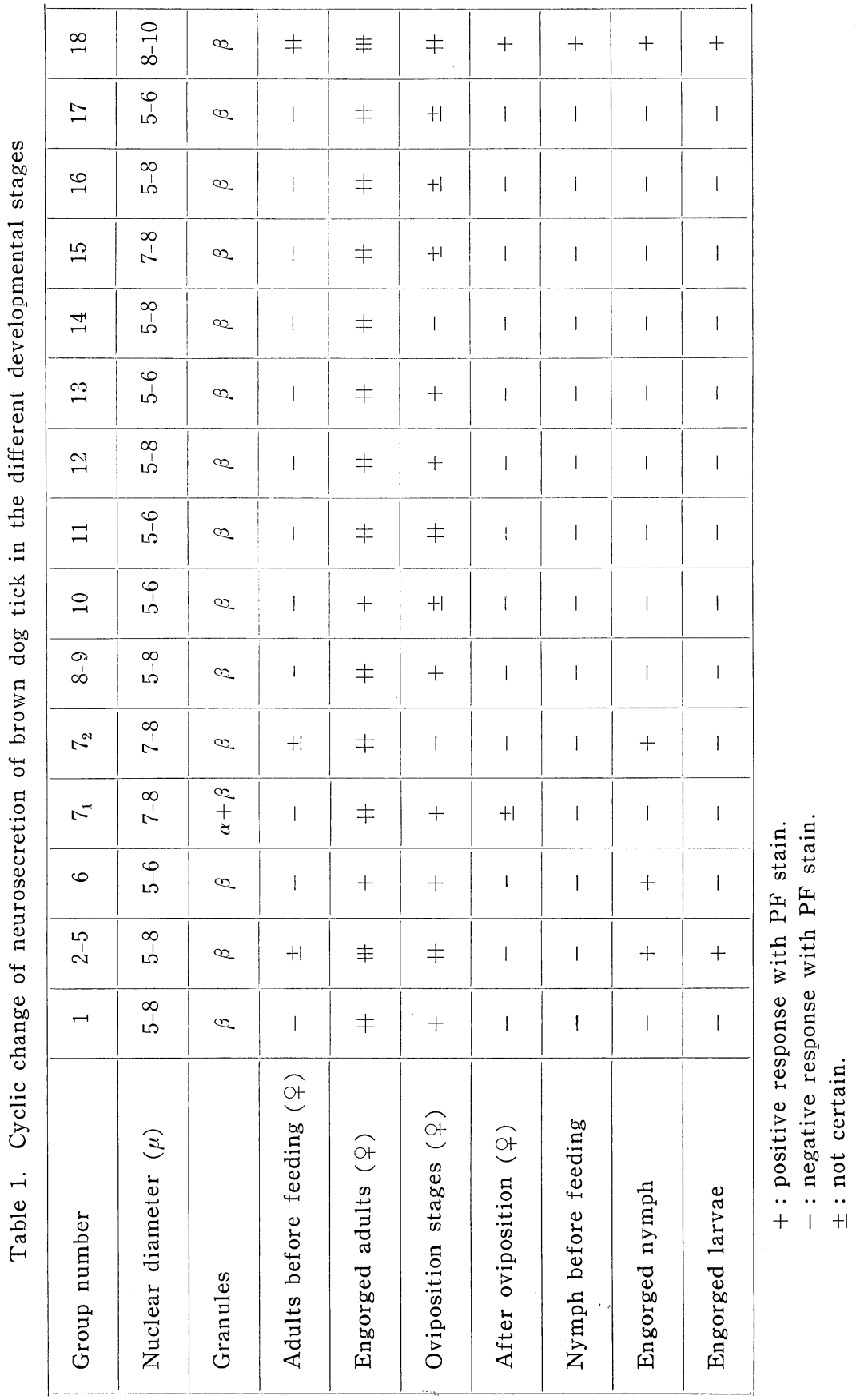


a light microscope. A neurohemal organ has been described in hard ticks by GABE (1955), and in soft ticks by EICHENBERGER (1970). Therefore these spherical structures, like the corpora cardiaca in insects (TURNER, 1966; NovAK, 1966; KONO, 1972), are possibly neurohemal organs.

In paraffin sections, the PF stain, followed by CHP, gave good results, but the R-F stain failed. As pointed out by IOFFE (1964), the PF positive neurosecretory cells in the brain were located both in the dorsal and ventral masses. In the former, the cells are situated close to the cerebral ganglion (Fig. 2 a, b) and in the latter, are situated in the peripheral region (Fig. $2 \mathrm{c}$ ).

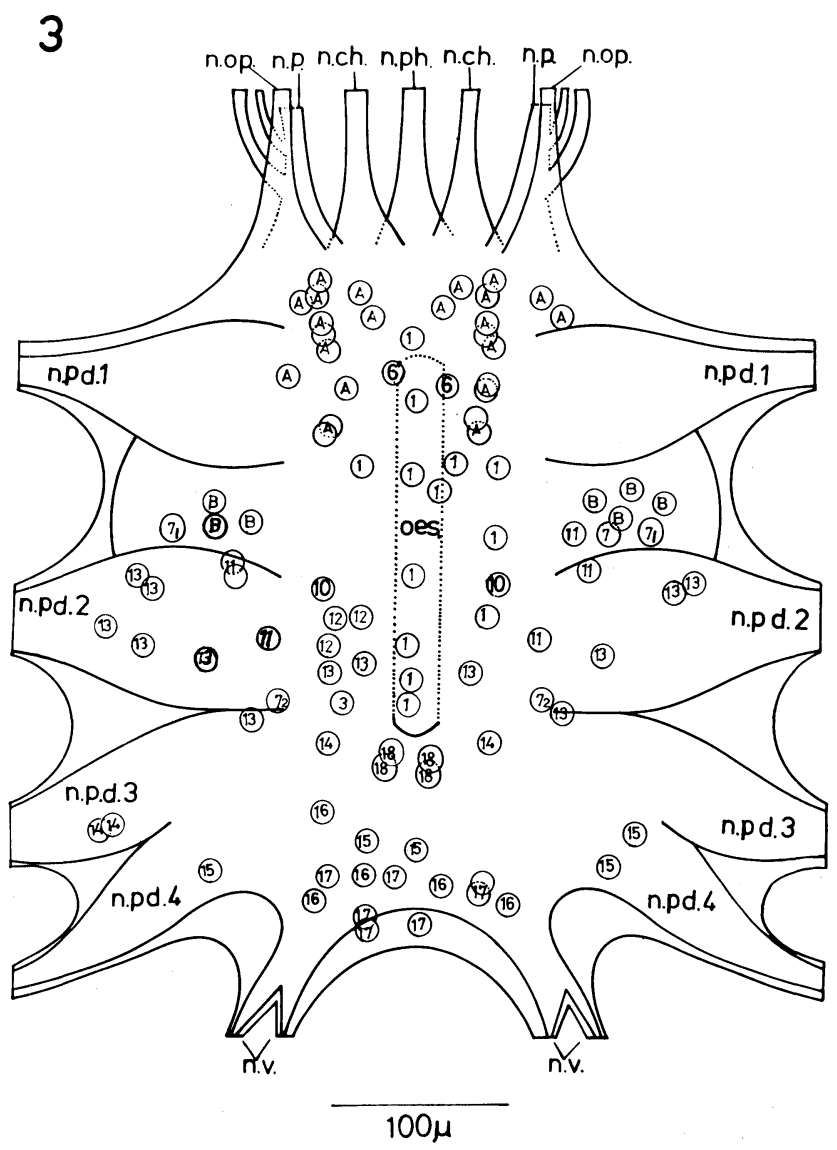

Fig. 3. The distribution of neurosecretory cells in the engorged adult female stage. oes: oesophagus; A: groups 2-5, B: groups 8-9. (other labels same as Fig. 1). 
By using IOFFE's nomenclature, 15 grouped cells could be located. They are groups $1,2-5,6,7,72,8-9,10,11,12,13,14,15,16,17$ and 18 . The majority of these cells contain basophilic particles- $\beta$ type (stained blue with PF, Fig. 2 a, c) except cell $7_{1}$ which contains both basophilic and acidophilic particles- $\alpha$ types (stained yellow with PF, Fig. 2 b). The nuclear diameter of the $\beta$-type cells varied from $5 \mu$ to $10 \mu$ with most in the $5-7 \mu$ range. The secretory phase of each cell as related to the different developmental stages is summarized in Table 1 and Fig. 3. In the ventral ganglion, cells of group 18 (Fig. 2 c) have the largest nuclei $(8-10 \mu$ in diameter) and show active secretion during all stages studies. These cells can be distinguished from motor neurons (with 2 nucleoli) by the presence of only $\beta$ granules and 1 nucleolus (Fig. 2 c) (CHOw et al., 1973). Evidently, these cells are related to the normal cell physiological function such as growth, metabolism etc. In the dorsal ganglion, most cells of groups 2, 3, 4 and 5 are clumped together and easily identified by the absence of nucleoli and smaller nuclei. Since these 4 cell groups can be stained by both PF and VB stains, they are treated as 1 cell group (groups $2-5$ or $\mathrm{A}$ in Fig. 3). In a hard tick life cycle, there are 2 ecdyses, one following the larval engorgement and another after the nymph engorges. Because cells of groups $2-5$ react positively after the larval and nymphal stages have fed, it is evident that neurons of this type secret a factor which initiates ecdysis. In insects, ecdysis is controlled by a brain hormone (GILBERT, 1964).

Other grouped cells such as 6 and $7_{2}$ which are situated close to the oesophagus, show active secretion in both the engorged adult and nymphal stages and are possibly related to the digestive mechanism. Whereas cells of grouped $7_{1}(\alpha$-cell), 8-9,10,11,12,13,14, 15, 16, 17 show active secretion only in engorged adults and are probably related to the maturation of the reproductive system. Morphologically speaking, this last group of neurons are more or less in the peripheral region of the posteriorly part of tick brain. It is therefore reasonable to incorporate their function with visceral relationships.

Ultrastructural details shown by electron microscope studies confirm that both dorsal (Fig. 5) and ventral masses (Fig. 6a, 7 a) contain neurosecretory neurons. The neurosecretory opaque granules within the cytoplasm of cells of groups $2-5$ are 2 sizes: the smaller granules are $400 \AA-700 \AA$ in diameter $\left(\mathrm{NG}_{1}\right)$ and the larger granules $1200 \AA-3000 \AA$ in diameter $\left(\mathrm{NG}_{2}\right)$. There is a 


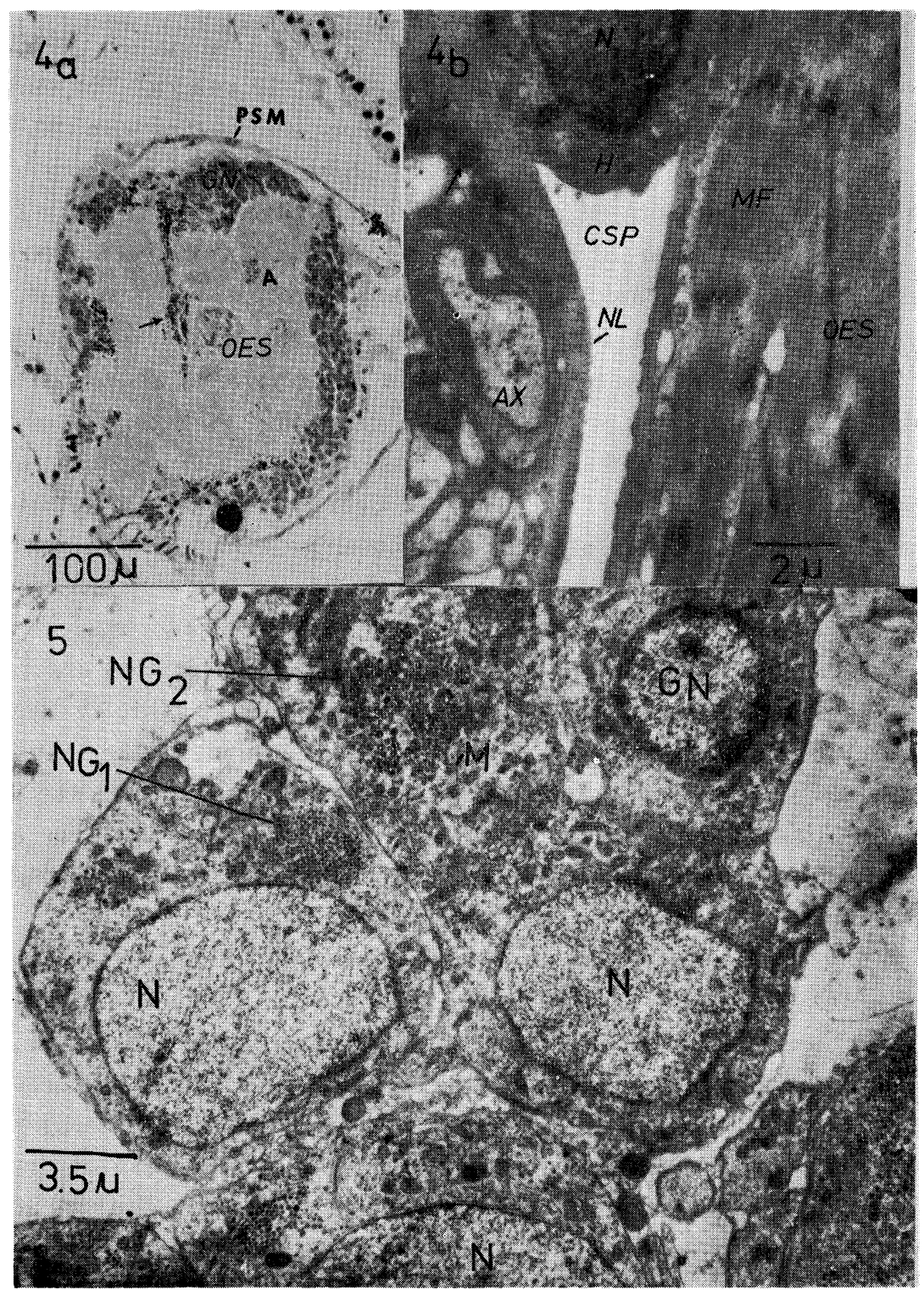

Fig. 4. a. Horizontal section of brain mass of female brown dog tick, showing axon flow of the neurosecretory material of groups 2-5 (A) and other cells (arrow), oesophagus (oes), periganglionic sinus membrane (PSM) (CHP stain).

b. Electron micrograph of circular space (CSP) between oesophagus (oes) and brain of brown dog tick, showing hemocyte $(\mathrm{H})$ and neurosecretory granules within axon (AX) and outside axon (arrow). neural lamella: (NL), myofibril (MF).

Fig. 5. Electron micrograph of Victoria blue and PF positive neurosecretory cells of type 2-5 in dorsal mass of brown dog tick. Ganglionic neuron (GN), mitochondria $(\mathrm{M})$, nucleus $(\mathrm{N})$, neurosecretory granules 1 and $2\left(\mathrm{NG}_{1}\right.$ and $\left.\mathrm{NG}_{2}\right)$. 

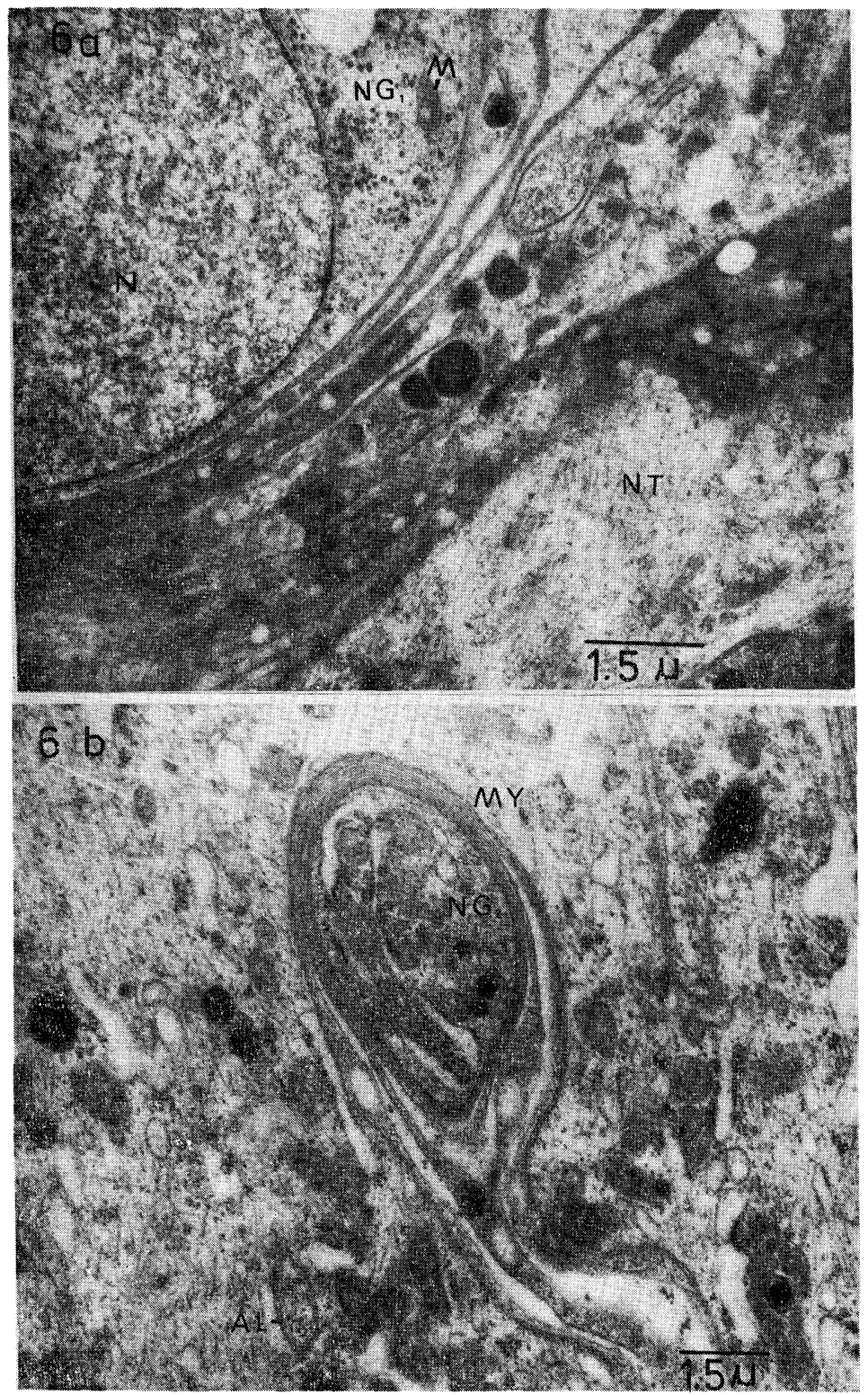

Fig. 6. a. Electron micrographs of neurosecretory neurons in ventral ganglion close to the neuropile region, showing numerous neurosecretory granules $\left(\mathrm{NG}_{1}\right)$, mitochondria (M), nucleus $(\mathrm{N})$ and neurotubules $(\mathrm{NT})$.

b. Note organized myelin-like structure (MY) enclosing neurosecretory granules $\left(\mathrm{NG}_{2}\right)$. Autophagic lysosome $(\mathrm{AL})$. 


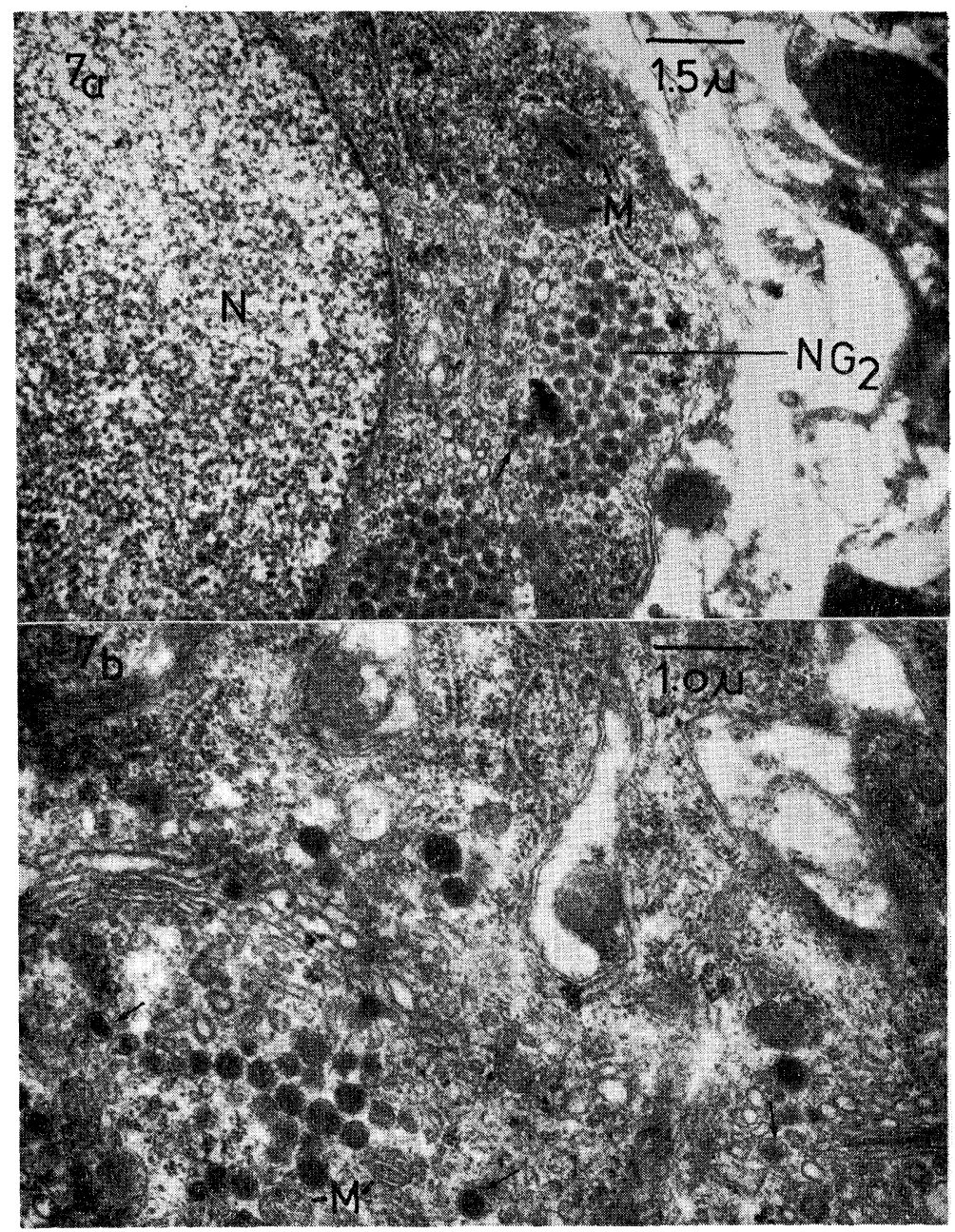

Fig. 7. Electron micrograph of the neurosecretory neuron in the periphery region of the ventral ganglion showing the neurosecretory granules $\mathrm{NG}_{2}$ and plenty ribosomes, mitochondria (M) in the perikarya.

b. Same as a, but with enlarged area of Golgi cisternae and showing many mitochondria (M), ribosomes and packaged neurosecretory materials (arrow).

tendency for $\mathrm{NG}_{1}$ to be always in the perikarya of small nuclear neuron, whereas $\mathrm{NG}_{2}$ are in the large nuclear neuron. Both granules can be also found in ventral ganglion (Fig. $6 \mathrm{a}, 7 \mathrm{a}$ ). As shown (Fig. $7 \mathrm{a}$ ), the active neuron contains more cisternae of the ribosome bearing endoplasmic reticulum and unattached ribosomes. Within the Golgi in the perikaryon, many secre- 

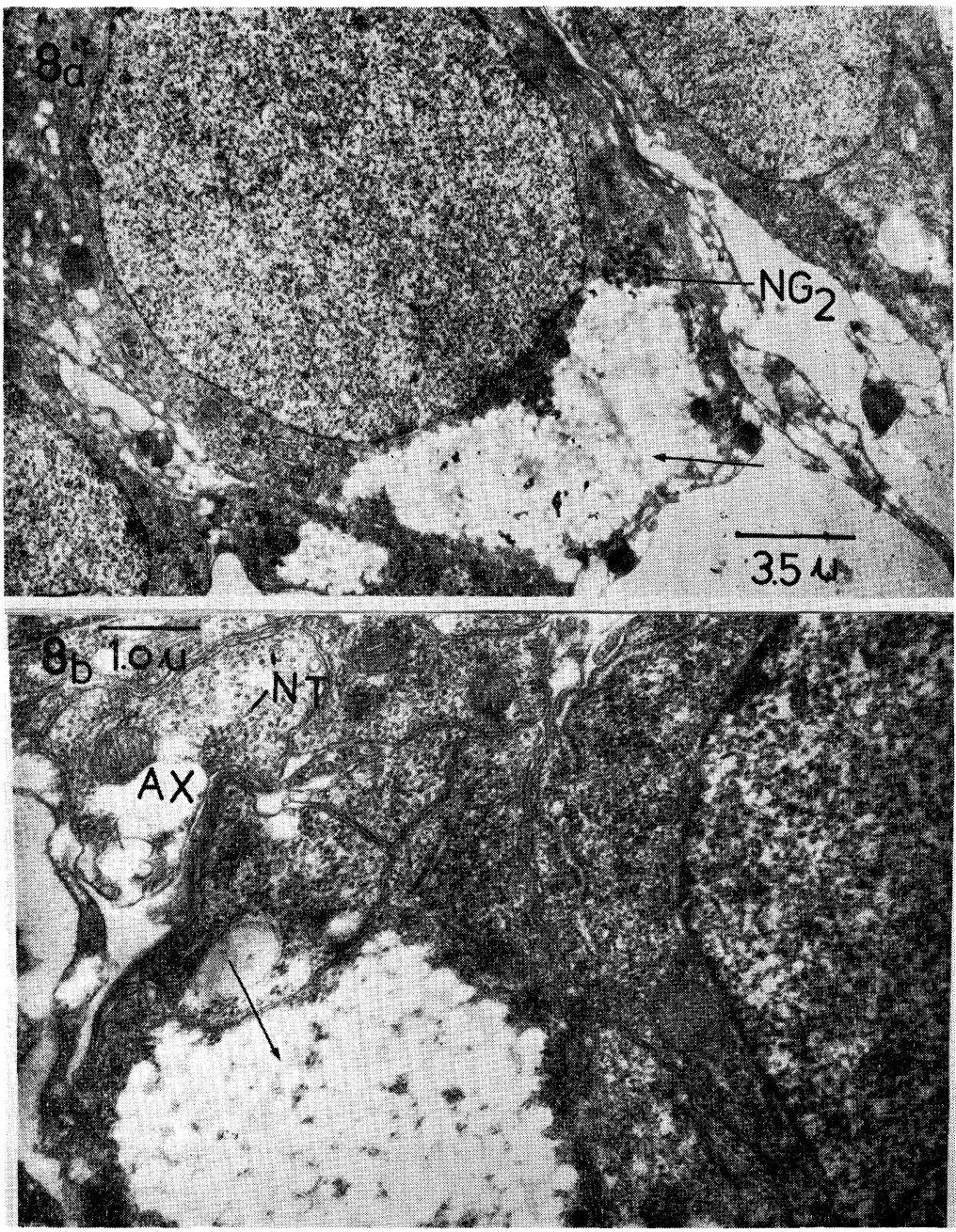

Fig. 8. a. Electron micrograph of the electron lucent vesicles (arrow) and neurosecretory granules $\mathrm{NG}_{2}$ in the cortex region showing that they are located in the perikarya of one cell.

b. Enlarged view of the electron lucent vesicles (arrow) close to the axon (AX). neurotubules (NT).

tory materials are packaged (Fig. $7 \mathrm{~b}$ ). This observation is similar to those obtained from insects by SMith (1968), MAdDRELL (1965), BEATTIE (1971), MARKs et al. (1973), from mites by Coons and Axtell (1971) and from soft ticks by EICHENBERGER (1970). In addition to the opaque (dense) droplets, 
the electron lucent vesicles (MADDRELL, 1970) are also found (Fig. $8 \mathrm{a}, \mathrm{b}$ ). These vesicles possibly are lipophilic materials, because the dehydration agents used were propylene oxide and ethanol. Biosynthesis of insect moulting hormones (ecdysone and crutecdysone) from cholesterol in the brain-ring gland complexes has been reported by WILlig et al. (1973). Whereas the true contents of these vesicles are not known. In the neurosecretory axon (Fig. 6b), the neurosecretory materials are enclosed by a well organized glial sheath. This myelin-like structure (MY) is quite similar to that of suboesophageal ganglion in the silkworm, Bombyx mori, as described by PARK and Yoshitake (1971). However, in insects, many small myelin-like structures have been identified as degenerated mitochondria (BERTRAM and SHIMADA, 1972). In ticks, both active mitochondria and small myelin structures were found.

Results of light microscope studies show that there is an aggregation of neurosecretory material close to the oesophagus (Fig. 4 a). The circular space around the oesophagus and that of the periganglionic membrane were also examined with electron microscopy; no direct opening between the brain and the hemocoele could be traced. In insects, the neural lamella of the brain, the sheath of the oesophagus and the aorta membrane have been described by Smith (1968), Aggarwal \& King (1971) and Huddart (1971). Similar neural lamella (Fig. $4 \mathrm{~b}$ ) composed of collegen fibrils are present in ticks. Because the granules are found only inside the thick lamella structure, they are probably released into the hemolymph first, and then transported by it to activate the target organ. Since the brain is bathed both outside (periganglionic sinus) and inside (circular space of oesophagus) with hemolymph, it is reasonable to say that the hemolymph is involved in the transportation of the neurosecretory granules. However, it appears that the neurosecretory granules are also transported directly to the distal part by pedal nerves. This is supported by the presence of neurosecretory materials within the longitudinal section of the pedal nerve we examined. Thus in ticks, neurosecretory granules are probably transported by 2 ways, hemolymph and ordinary nerve axon to activate such remote sites as the tarsal glandular organ, dermal gland, etc. (Chow et al., 1972; Foelix and Axtell, 1972). 


\section{Acknowledgements}

We express our deep appreciation to Dr. A.P. GUPTA, Dept. of EntomologyEconomic Zoology, Rutgers University, and Dr. F. R. SAntana, Dept. of Medical Ecology, U.S. NMRU No. 2 for their review of the manuscript.

\section{References}

AgGarwal, S. K. \& R. C. King. 1971. An electron microscopic study of the corpus cardiacum of adult D. melanogaster and its afferent nerves. J. Morphol., 134: 437446.

BEATtie, T. M. 1971. Histology, histochemistry, and ultrastructure of neurosecretory cells in the optic lobe of cockroach, P. americana. J. Insect Physiol., 17: 1843-1845.

Berger, R.S., J.C. Dukes \& Y.S. Chow. 1971. Demonstration of a sex pheromone in three species of hard ticks. J. Med. Entomol., $8: 84-86$.

Bertram, S. \& Y. Shimada. 1972. Degenerative changes in the mitochondria of flight muscle from aging blowflies. J. Cell Biology, 52: 465-477.

Burgess, L. \& J.G. Rempel. 1966. The stomodaeal nervous system, the neurosecretory system, and the gland complex in Aedes aegypti (L.) (Diptera: Culicidae). Can. J. Zool., $44:$ 731-765.

Chow, Y.S. 1970. Sex pheromone and behavioral studies of the adult Gulf Coast tick (Amblyomma maculatum $\mathrm{KoCH}$ ) including morphological and electrophysiological studies of the sensory organs. Ph. D. thesis. Auburn Univ. Auburn, U.S. A.

Chow, Y.S., P. C. Cheng \& S. H. Lin. 1973. Motor neuron map of tropical Cattle tick, Boophilus microplus (Canestrini) (Acarina: Ixodidae). Intern. J. Insect Morphol. Embryol., 2 : 305-311.

Chow, Y.S., S. H. LiN \& J.S. Su. 1972. A new tarsal gland of the brown dog tick, R. sanguineus (Latreille), 1804 (Acarina: Ixodidae). Bull. Inst. Zool., Academia Sinica, 11(2): 35-9.

Coons, L.B. \& R.C. Axtell. 1971. Cellular organization in the synganglion of the mite Macrocheles muscaedomesticae (Acarina: Macrochelidae): An electron microscopic study. Z. Zellforsch., 119: 309-320.

DhANDA, V. 1967. Changes in neurosecretory activity at different stages in adult Hyalomma dromedarii Koch, 1844. Nature (London), 214: 508-509.

DogRA, G.S. \& B.K. TANDAN. 1964. Adaptation of certain histological techniques for in situ demonstration of the neuro-endocrine system of insects and other animals. Quart. J. Microsc. Sci., 105(4): 455-466.

Douglas, J. R. 1943. The internal anatomy of D. andersoni Stiles. Univ. Calif. Publ. Entomol., $7:$ :207-272.

Dutkowski, A. B., B. Cymborowski \& A. Przelecka. 1971. Circadian changes in the ultrastructure of neurosecretory cells of the pars inter cerebralis of the house cricket. J. Insect Physiol., $17:$ 1763-1772.

Eichenberger, G. 1970. Das Zentralnervensystem von Ornithodorus moubata (MurRAY), Ixodoidea: Argasidae, und seine postembryonale Entwicklung. Acta. Trop., $27: 15-23$.

Finlayson, L.H. \& M. P. Osborne. 1970. Electrical activity of neuro-hemal tissue 
in the stick insect Carausius morosus. J. Insect Physiol., 16: 791-800.

Foelix, R. F. \& C. Axtell. 1972. Ultrastructure of Haller's organ in the tick, $A$. americanum (L.). Z. Zellforsch., 124: 275-292.

GabE, M. 1955. Donnees histologiques sur la neurosecretion chez les Arachnides. Arch. Anat. micr. Morph. exp., $44: 351-383$.

Gilbert, L. I. 1964. Physiology of growth and development: endocrine aspects. pp. 149-225. In M. Rockstein (ed.), The Physiology of Insect. Vol. 1 The Academic Press, N. Y.

Hofer, H. O. 1968. The phenomenon of neurosecretion, pp. 461-517. In G. H. Bourne (ed.). The Structure and Function of Nervous Tissue. Vol. 1 The Academic Press, N. Y.

HudDART, H. 1971. Ultrastructure of the prothoracic ganglion and connective of the stick insect in relation to function. J. Insect Physiol. 17: 1451-1469.

Humason, G.L. 1967. Animal Tissue Technique. W. H. Freeman \& Co. San Francisco, Calif. 569 p.

IOFFE, I. D. 1964. Distribution of neurosecretory cells in the central nervous system of D. pictus Herm. (Acarina, Chelicerata). Dokl. (Proc.) Acad. Sci. USSR, Biol. Sci. Sect., 154(1-6) : 25-29.

ItTycheriah, P. I. \& E. P. MARKs. 1971. Performic acid-resorcin fuchsin: A technique for the in situ demonstration of neurosecretory material in insects. Ann. Entomol. Soc. Amer., 64 : 762-765.

Kono, Y. 1972. Ultrastructure of the brain-corpus cardiacum system at the time of the humoral determination of diapause in Pieris rapae crucivora Boischuval-III. Neurosecretory axons and corpus cardiacum. Jap. J. Appl. Entomol. Zool., 16 : 5966.

MAddrell, S.H. P. 1965. Neurosecretory supply to the epidermis of an insect. Science, $150: 1033-1034$.

Maddrell, S. H. P. 1970. Neurosecretory control system in insects. pp. 101-116. In A.C. Neville (ed.), Insect Ultrastructure. Blackwell Scientific Publications, Oxford.

Marks, E. P., G. M. Holman \& T. K. Borg. 1973. Synthesis and storage of a neurohormone in insect brains in vitro. J. Insect Physiol., 19: 471-477.

Nathanson, M.E. 1970. Changes on the fine structure of the integument of rabbit tick, H. leporispalustris (Acari: Ixodides: Ixodidae) which occur during feeding. Ann. Entomol. Soc. Amer., 63 : 1778-1774.

NovaK, V. J.A. 1966. Insect Hormones. Methuen \& Co., Ltd. London.

PARK, K.E. \& N. Yoshitake. 1271. Fine structure of the neurosecretory cells in the suboesophageal ganglion of the silkworm, B. mori. J. Insect Physiol., 17: 13051313.

Smith, D.S. 1968. Insect Cells, Their Structure and Function. Oliver \& Boyd, Edinburgh. 372 pp.

Smith, D.S. \& J.E. Treherne. 1963. Functional aspects of the organization of the insect nervous system, pp. 401-484. In J. W. L. BeAment, J. E. Treherne and V.B. Wigglesworth (ed.), Advances in Insect Physiology. Vol. 1, The Academic Press, N. Y.

Tsvileneva, V.A. 1965. The nervous structure of the ixodid synganglion (Acarina, Ixodidae). Entomol. Rev., 44 : 135-142. 
Turner, C. D. 1966. General Endocrinology. Saunders Co., Philadelphia \& London. Willig, A., H. H. Rees \& T. W. Goodwin. 1971. Biosynthesis of insect moulting hormones in isolated ring glands and whole larvae of Calliphora. J. Insect. Physiol., $17: 2317-2327$. 